a highway for people passing north and south. But why for 30 miles or so folk should have taken the trouble to cover rocks with stylized figures of animals, men and signs remains a mystery. It is easy to talk about ritual, but that does not answer the question. Why the ritual, and what was it ? Similar rock art complexes are known, the most famous being those surrounding Monte Bego in the Ligurian Alps. While there is a certain similarity with those of the Val Camonica, there are also notable differences (the characteristic halberds of Monte Bego seem to be replaced by spears at Val Camonica and I do not remember any stags at Monte Bego), and in any event their connexion would rather be with the earlier series at the Val Camonica than with the later. At Monte Bego there is a thunderstorm almost daily at 3 p.m., due to the fact that it is the first high mountain inland from the hot Riviera coast. Local peasants, when asked what the weather will be, still say, "Let me see what the devil at Monte Bego is doing". One can imagine a reason for a ritual to take place from time to time at that mountain, but at Val Camonica such a reason would seem to be absent.

M. Anati is to be congratulated on producing a very useful and much-wanted work. Two criticismas must be added. No general index is supplied, and while there are references to a fow works in the text, there is no bibliography. This is a real nuisance. French publications seldom carry any index : a policy to be questioned. In the present case, its absence is a great inconvenience. But these two defects must not be allowed to detract from the real value of M. Anati's excellent work. MuLes BuRKITT

\title{
HYPOTHERMIA AND THE EFFECTS OF COLD
}

\begin{abstract}
$\mathrm{T}$ THE modern investigation of hypothermia in man can be said to date from the work of Temple Fay and G. W. Smith, carried out during 1938-39. They cooled patients suffering from inoperable carcinoma, in the hope that the lowered temperature would affect the new growth more than the rest of the body. The clinical work was complemented by physiological work by D. B. Dill and W. H. Forbes on hypothermic patients.

During the Second World War hypothermia became important as a factor in survival at sea. Shipwreck survivors rescued after prolonged immersion frequently died because of lowered body temperature. Much work on the effects of body-cooling was thus stimulated, with emphesis on the treatment of hypothermia rather than on its clinical use. After the War, A. H. Hegnauer and his associates at Boston started a systematic investigation of the physiology of hypothermia in the dog, and about the same time W. G. Bigelow began his work at Toronto with the possibility of using hypothermia as a surgical tool.

Since 1950, the subject has advanced very rapidly, particularly as the surgical advantages of hypothermia have become apparent. Smith and Fay reduced body-temperature to between $30^{\circ} \mathrm{C}$. and $32^{\circ} \mathrm{C}$., and this was a hazardous procedure. For a long time it was found to be dangerous to lower
\end{abstract}

\section{OPEN FORESTS IN TROPICAL AFRICA}

the temperature to below $27^{\circ}$ C. Now C. E. Drew and his colleagues cool their patients to below $15^{\circ} \mathrm{C}$.

A recent issue of the British Medical Bulletin contains a fascinating collection of articles describing present investigations and how the techniques of hypothermia are being used in medicine and surgery (17, No. 1 ; January 1961 : Hypothermia and the Effects of Cold. Pp. 1-78+xvii. London: British Council, 1961. 20s.). The articles include one by R. W. Salt on the resistance of poikilothermic animals to cold; hibernation in mammals by Dr. L. Harrison Matthews; local cooling in man by Dr. R. H. Fox; physiological effects of continued cold on animals and man by J. S. Hart; biochemicel changes in exposure and acclimatization to cold environments by Dr. F. Depoces; the technique of induced hypothermia by Drs. I. K. R. McMillan and E. S. Machell; profound hypothermia in cardiac surgery by Dr. C. E. Drew. Other articles include accounts of experimental deep hypothermia and the circulation in hypothermia; metabolism in hypothermia; hormones in hypothermia; the central nervous system in hypothermia and the effect of temperature on the response to drugs; and sensitivity of hypothormic mammals to X-irradiation. Prof. A. S. Parkes has acted as co-ordinator of the whole series.

\footnotetext{
DUBliCATION No. 52, issued by the Scientific Council for Africa South of the Sahara, contains selected papers presented at a conference of British, French, Belgian and Portuguese specialists held at Ndola, Northern Rhodesia, during November 17-23, 1959 , and also the recommendations made and the conclusions reached*.

The conference considered the forestry problem of what is generally referred to as miombo woodland which, from Katanga (Congo) to Southern Rhodesia,

* Scientifle Council for Africa South of the Sahara. CSA/CCTA Publication No. 52. Pp. 126. (London: Bureau of Publications, CCTA/CSA Secretariat, Watergare House, York Bulldings, W. 0.2 1960.)
}

covers some 670,000 square miles. The term miombo embraces several forest types ranging from dry high forest to savannah-woodland, but Brachystegia species are fairly typical of the treo canopy.

The sylviculture and management of the miombo woodland are made difficult by the large areas, the damage caused by fires, the low proportion of valuable species, the slow rate of growth, the long haulage distances, the limited uses of timbers which are not easy to work, slow to season, not durable and sometimes not possible to impregnate. Pterocarpus angolensis and the so-called Rhodesian teak, Baikiaea plurijuga, provide timber for constructional 